\title{
Воспитание собаки
}

Технология

Гаргало А.Г.

6 класс, МАОУ СШ №137, г. Красноярск

Научный руководитель: Деяк И.А., учитель технологии, МАОУ СШ №137, г. Красноярск

\section{ВВЕДЕНИЕ}

Собака - первое домашнее животное, прирученное человеком. По мере того как изменялись условия жизни человека, видоизменялись и способы применения собак.

Человек очень давно оценил полезные качества собаки: острое обоняние, тонкий слух, хорошее зрение, быстрый бег, выносливость и неприхотливость.

Bce это сделало собаку незаменимой для выполнения многих народнохозяйственных, военных задач и в наши дни $[1$, с. 3$]$.

Дрессировка - это последовательное, направленное приучение животных к совершению в определенных условиях разнообразных сложных действий, необходимых для несения службы (работы) [2, с. 4].

В наши дни многие породы собак были выведены специально для содержания в квартире и участия в выставках. Маленькие собаки с шелковистой шерстью созданы не для того, чтобы охранять дом или охотиться, а для того, чтобы радовать своих хозяев своим внешним видом и покладистым поведением.

Однако, даже крохотный декоративный пёс нуждается в дрессировке и воспитании, чтобы его содержание приносило только положительные эмоции.

\section{ЦЕЛЬ ИССЛЕДОВАНИЯ}

\section{Актуальность:}

В наше время одним из самых популярных животных является лучший друг человека - собака. Но, чтобы животное приносило только радость, а не убытки в виде поломанной мебели и порванной одежды, с собакой нужно заниматься дрессировкой и воспитанием. 
К сожалению, услуги профессиональных кинологов стоят очень дорого, к тому же, хозяин сам должен найти подход к своей собаке, дабы в будущем не допустить непослушания.

Поэтому я предлагаю дрессировать Вашего любимца самостоятельно.

\section{Проблема:}

Когда родители подарили мне собаку, я столкнулась с проблемой - собака начала портить мебель и вещи. Тогда я поняла, что с питомцем нужно заниматься дрессировкой.

\section{Цель:}

Обучить собаку командам и послушанию.

\section{Задачи:}

- Познакомиться с психологией собаки;

- Разработать программу для дрессировки;

- Проводить ежедневные занятия по дрессировке собаки;

- Управление собакой в повседневной жизни.

\section{МЕТОДЫ ИССЛЕДОВАНИЯ}

Наблюдение за повадками питомца.

Нужно понять, в каком случае и по какой причине питомец делает те или иные вещи);

Знакомство с психологией собак;

Этот этап можно разделить на несколько подгрупп:

1. Опрос знакомых, у кого есть собака.

2. Ознакомление с психологией собак (послушать советы опытных кинологов).

3. Наблюдение за своей собакой.

Разработка программы по воспитанию собаки в зависимости от возраста, породы и причин плохого поведения собаки; 
Обучение собаки командам и послушанию с помощью разработанной программы;

Внесение корректировок в программу обучения (при необходимости).

\section{Oпрос}

Собаку очень часто можно встретить в роли домашнего животного. Но для того, чтобы она была послушной, хозяева занимаются дрессировкой со своим питомцем.

Я считаю очень важным - расспросить опытных собаководов, услышав от них ответы на интересующие вопросы и советы по воспитанию собаки.

\section{Вопросы}

- Как Вы обучали Вашу собаку, какие методы применяли (в зависимости от породы)?

- Какие трудности у Вас возникали при дрессировке собаки?

- С кем лучше обучается собака - с кинологом или с хозяином (для тех, кто обращался к кинологу)?

- В каком возрасте собака лучше поддается дрессировке?

В зависимости от ответов собаководов, я составила таблицу, по которой можно понять все ответы на вопросы (таблица 1).

Таблица 1. Ответы на вопросы.

\begin{tabular}{|c|c|c|c|c|c|c|}
\hline Вопросы & $\begin{array}{c}\text { Ответ } \\
\text { собаковода } \\
\text { №1. }\end{array}$ & $\begin{array}{c}\text { Ответ } \\
\text { собаковода } \\
\text { №2 }\end{array}$ & $\begin{array}{c}\text { Ответ } \\
\text { собаковода } \\
\text { №3 }\end{array}$ & $\begin{array}{c}\text { Ответ } \\
\text { собаковода } \\
\text { №4 }\end{array}$ & $\begin{array}{c}\text { Ответ } \\
\text { собаковода } \\
\text { №5 }\end{array}$ & $\begin{array}{c}\text { Ответ } \\
\text { собаковода } \\
\text { №6 }\end{array}$ \\
\hline $\begin{array}{c}1 . \text { Самые } \\
\text { легко } \\
\text { обучаемые } \\
\text { породы }\end{array}$ & Пудель & $\begin{array}{c}\text { Немецкая } \\
\text { овчарка }\end{array}$ & Доберман & Шелти & Папильон & Ротвейлер \\
\hline
\end{tabular}




\begin{tabular}{|c|c|c|c|c|c|c|}
\hline $\begin{array}{c}\text { 2.Самые } \\
\text { трудно } \\
\text { обучаемые } \\
\text { породы }\end{array}$ & Чау-чау & Пекинес & $\begin{array}{c}\text { Афганская } \\
\text { борзая }\end{array}$ & Басендж & Мастифф & Бладхаунд \\
\hline $\begin{array}{c}\text { 3.Трудност } \\
\text { и при } \\
\text { обучении }\end{array}$ & $\begin{array}{c}\text { Собака } \\
\text { отвлекается }\end{array}$ & $\begin{array}{c}\text { Собака } \\
\text { начинает } \\
\text { бояться }\end{array}$ & $\begin{array}{c}\text { Собака не } \\
\text { понимает, } \\
\text { что от неё } \\
\text { хотят }\end{array}$ & $\begin{array}{c}\text { Собака } \\
\text { отвлекается }\end{array}$ & $\begin{array}{c}\text { Собака } \\
\text { отвлекается }\end{array}$ & $\begin{array}{c}\text { Собака } \\
\text { начинает } \\
\text { бояться }\end{array}$ \\
\hline $\begin{array}{c}\text { 4.С кем } \\
\text { собака } \\
\text { обучается } \\
\text { лучше и } \\
\text { спокойней. }\end{array}$ & С хозяином & С хозяином & С кинологом & С хозяином & С хозяином & С кинологом \\
\hline $\begin{array}{c}\text { 5.Какой } \\
\text { возраст для } \\
\text { обучения }\end{array}$ & Щенок & Щенок & $\begin{array}{l}\text { Взрослая } \\
\text { собака }\end{array}$ & Щенок & $\begin{array}{c}\text { Взрослая } \\
\text { собака }\end{array}$ & $\begin{array}{l}\text { Взрослая } \\
\text { собака }\end{array}$ \\
\hline
\end{tabular}

Существуют породы собак, которые обучаются сложнее, чем другие. Согласно опросу, удалось узнать, что тяжело поддаются дрессировке такие породы собак как пекинес, афганская борзая, чау-чау.

Трудности, которые возникают у хозяев при дрессировке выражаются в том, что собака боится, отвлекается от обучения и не понимает, чего от неё хотят.

По результатам опроса стало ясно, что большинство хозяев выбирают самостоятельное обучение своего питомца.

В опросе про возраст дрессировки собаки мнения моих знакомых разделились, однако, согласно советам кинологов, мне удалось узнать, что лучше всего дрессировке поддается собака в щенячьем возрасте. Занятия можно проводить с 3 месяцев.

Теперь можно поговорить про самые банальные ошибки из-за которых возникают трудности при дрессировке.

Первая трудность проявляется, когда собака начинает отвлекаться от дрессировки. Чаще всего это возникает при дрессировке щенков, но и встречается у взрослых собак. Чтобы этого не происходило, достаточно убрать 
все отвлекающие факторы и убедиться в том, что в комнате нет посторонних людей, ведь именно из-за этого чаще всего возникает данная проблема.

Вторая трудность, которая возникает очень часто выражается в том, что собака не понимает, чего от неё хотят. Для решения этой проблемы можно попробовать несколько способов. Изменить жест при обучении, так-как чтобы обучить собаку определённой команде очень важен жест руки, нужно объяснить любимцу, что ему нужно сделать. Сменить лакомство, ведь собаку нужно заинтересовать. Но главное помнить, что собака может не выполнять команду, когда она устала, у неё что-то болит или она чувствует себя некомфортно. В этом случае следует прекратить дрессировку на необходимый срок.

Последняя трудность, которую я хочу разобрать — это страх собаки в процессе дрессировки. Здесь виноват исключительно хозяин. Проблема кроется, в том, что хозяин сильно повышает голос. Нужно помнить, что собака не виновата в том, что она не выполняет команду. Чтобы решить проблему нужно просто перестать повышать голос на собаку.

\section{Программа по дрессировке}

Как ранее было сказано, я разработала программу по дрессировке собак, которая поможет добиться послушания питомца. Благодаря этой программе улучшится послушание питомца, и собака научится выполнять много команд.

Я составила план, по которому можно кратко понять, что будет в программе - по каким дням будет выполнятся та или иная команда. Программа составлена на 2 месяца.

Таблица 2. План на 1-ю неделю.

\begin{tabular}{|l|l|l|}
\hline \multicolumn{1}{|c|}{ Расписание } & \multicolumn{1}{|c|}{ Команда } & \multicolumn{1}{|c|}{$\begin{array}{c}\text { Продолжительность } \\
\text { дрессировки }\end{array}$} \\
\hline Понедельник & Приручение к кличке & 5 минут в день \\
\hline Вторник & Приручение к кличке & 5 минут в день \\
\hline Среда & Приручение к кличке & 5 минут в день \\
\hline
\end{tabular}




\begin{tabular}{|l|l|l|}
\hline Четверг & Приручение к кличке & 5-7минут в день \\
\hline Пятница & Приручение к кличке & 5-7 минут в день \\
\hline Суббота & Приручение к кличке & 5-7 минут в день \\
\hline Воскресенье & Приручение к кличке & 5-7 минут в день \\
\hline
\end{tabular}

\section{Приучение к кличке.}

В первую неделю я предлагаю приучить питомца к кличке. Это важно для того, чтобы в дальнейшем можно было выполнять другие команды.

Для обучения понадобится лакомство. Необходимо отойти от собаки на 2 метра и произнести ее кличку так, чтобы это было сигналом внимания. Кличку нужно говорить коротко и ясно, с ласковой интонацией. Важно - кличку нельзя изменять. Произношение должно быть таким, как и в последующем общении с собакой. Время обучения в день не должно превышать 7 минут.

Результат: за неделю собака научилась откликаться на кличку.

Таблица 3. План на 2-ю неделю.

\begin{tabular}{|l|l|l|}
\hline \multicolumn{1}{|c|}{ Расписание } & \multicolumn{1}{|c|}{ Команда } & \multicolumn{1}{|c|}{$\begin{array}{c}\text { Продолжительность } \\
\text { дрессировки }\end{array}$} \\
\hline Понедельник & «Сидеть» & 10 мин \\
\hline Вторник & «Сидеть» & 10 мин \\
\hline Среда & «Сидеть» & 10 мин \\
\hline Четверг & «Ко мне» & 10 мин \\
\hline Пятница & «Ко мне» & 10 мин \\
\hline Суббота & «Сидеть» & 10 мин \\
\hline Воскресенье & «Ко мне» & 10 мин \\
\hline
\end{tabular}

Обучение команде «Сидеть».

Для обучения этой команде я использовала контрастный метод дрессировки. Чтобы собака села, нужно обратить внимание собаки на вас с помощью клички, затем произнести команду «Сидеть», посадить собаку слегка надавив на ее крестец и завести лакомством за голову питомца, угостив его. 


\section{Обучение команде «Ко мне».}

Для этой команды нужно изначально отойти от питомца на 2 метра, произнести его кличку, чтобы обратить внимание собаки на себя, и похлопывая по своей ноге, позвать собаку к себе. Когда собака подошла необходимо похвалить ее и дать лакомство.

Потом можно отходить на более дальние расстояния перед тем, как позвать собаку.

На 4 неделе я предлагаю закрепить результат прошлой команды.

\section{Обучение команде «Лежать».}

Этой команде можно обучать питомца контрастным методом. Изначально необходимо дать собаке команду «Сидеть», а руку с лакомством опустить в низ, при этом помогая собаке - немного надавливая на холку.

Эта команда достаточно простая, но часто используется в жизни, из этой команды вытекают другие, например: «Ползи», «Кувырок», «Джельтелмен», «Спать».

\section{Обучение команде «Фу».}

Необходимо положить лакомство на пол и, когда собака потянется за ним, сказать строгим голосом команду «Фу», дёрнуть поводок, при этом продолжать движение.

Результат: собака обучилась команде «Фу» и, услышав ее, прекращает свое нежелательное поведение.

\section{Обучение команде «Ползи»}

Команда «Ползи» выполняется вкусопоощерительным методом. Нужно дать собаке команду «Лежать», а после этого отдалять свою руку с лакомством.

Результат: собака обучилась новой команде «Ползи».

7-ю неделю посвятить повторению всех изученных ранее команд. 
В последней неделе в моей программе, я бы хотела написать про 2 простых команды «Дай лапу» и «Кружись».

\section{Обучение команде «Дай лапу».}

Для обучения команде «Дай лапу» необходимо самому взять лапу собаки и похвалить словесно и, дав лакомство. Повторять данную много раз. Со временем собака сама будет давать лапу при команде.

\section{Обучение команде «Кружись».}

Для обучения команде «Кружись» необходимо рукой с лакомством крутить у носа собаки, так чтобы она сама кружилась за рукой вокруг себя.

Результат: собака обучилась команде «Дай лапу» и «Кружись».

\section{РЕШЕНИЕ ПРОБЛЕМЫ}

Для решения вышеописанной проблемы «Собака портить вещи и мебель» я решила использовать специальные игрушки.

Питомцу необходимо что-то грызть и тягать - это заложено в его подсознании, и у собаки режутся зубки. Но, если для игры нет специальных приспособлений, собака будет портить вещи и мебель.

Когда я обучала собаку команде «спать», я столкнулась с трудностями собака не хотела ложиться на бок. Никакие видео уроки мне не помогали решить эту проблему. Тогда я попробовала такой способ: сначала занималась дрессировкой собаки на кровати. Изначально я давала команду «лежать», а после этого заводила лакомство за голову, благодаря чему собака постепенно начала ложиться на бок. После того как собака хорошо выполняла команду «спать» на кровати, я начала заниматься ее дрессировкой на полу. Таким образом моя собака начала выполнять эту команду.

\section{Игрушка канатик.}


Сначала из любого куска ткани (это может быть старая кофта или футболка) вырезаем четыре одинаковых полоски (длинна будет зависеть от размера каната). Далее завязываем узел на конце и начинаем плести (ниже прикреплены фотографии). Когда нужная длинна достигнута, на конце завязываем узел. Игрушка готова!

Рисунок 1. Изготовление игрушки «Канат».

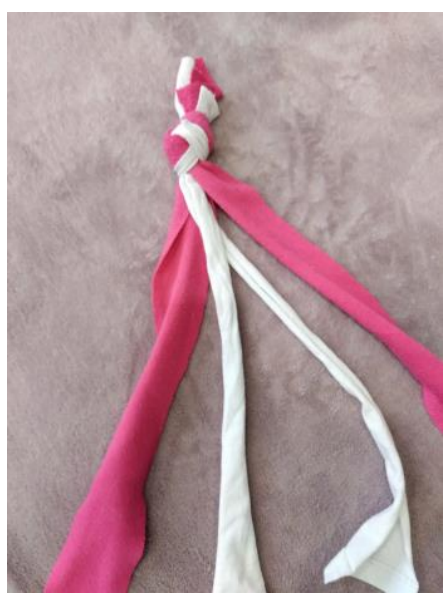

Рисунок 2. Готовая игрушка «Канат».

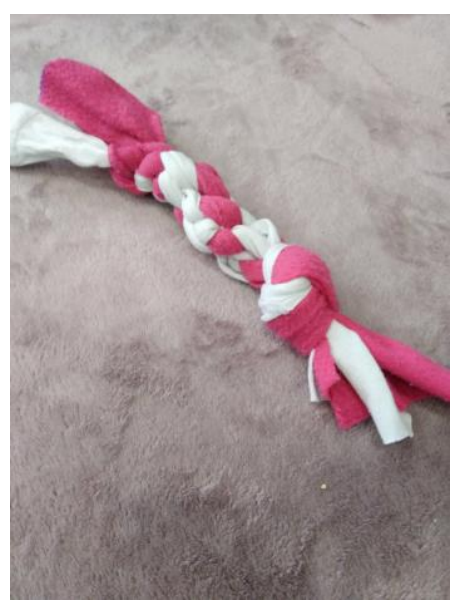

\section{ЗАКЛЮЧЕНИЕ}

Собаку называют другом человека, потому что она разделяет с нами самые опасные жизненные ситуации и приятные моменты. Некоторые собаки находят наркотики, ловят преступников. Есть собаки поводыри, которые помогают незрячим людям. Благодаря советам опытных кинологов и собаководов я обучила своего питомца выполнять некоторые те команды, чего ранее не удавалось. Также собака перестала портить мебель и вещи, улучшился контакт с собакой.

Благодаря этому проекту я вспомнила многие хорошие моменты связанные с моей собакой. Во время работы я узнала много нового и интересного.

\section{ЛИТЕРАТУРА}

1. Дрессировка служебных собак. Ф. С. Арасланов, А. А. Алексеев, В. И. Шигорин. [Текст] - Алма-Ата: Кайнар, 1987. - 301 с. 
2. Дрессировка служебных собак. Справочник по дрессировке собак. Л. И. Чебыкина. [Текст] - М.: Аквариум - Принт, 2011. - 410 с. ISBN 5-98435374-1

3. Перевоспитание собак. Справочник собаковода. В. В. Гриценко. [Текст] М.: Компания Дельта М., 2002 - 288c. ISBN 5-94107-082-9 